\title{
Management for Paddy, Oil Palm, and Pineapple Plantations in Malaysia: Current Status and Reviews
}

\author{
Sahil Mohedin Hawa a, Hillry Gibson Anak Panjanga, Ericson Nyaganga ${ }^{\mathrm{a}}$, Wan Sieng Yeo ${ }^{\mathrm{a}, *}$, \\ Agus Saptoro, Shiew Wei Lau ${ }^{\mathrm{a}}$, Tze Khiun Jong ${ }^{\mathrm{b}}$ and Alex Choon Teck Jong ${ }^{\mathrm{c}}$ \\ ${ }^{a}$ Department of Chemical Engineering, Curtin University Malaysia, CDT 250, 98009 Miri, \\ Sarawak, Malaysia. \\ ${ }^{b}$ Botanium Agro-Tech (M) Sdn. Bhd., Lot 1780, Taman Tunku Industrial Estate, 98000 Miri, \\ Sarawak, Malaysia. \\ ${ }^{c}$ Koperasi Pembangunan Pertanian Bersatu Timur Bhd., Senandin, Miri, Sarawak, Malaysia.
}

\begin{abstract}
Heavy rainfall causes a loss of fertiliser to the environment, and it leads to environmental issues such as eutrophication. Replenishment of fertiliser to replace the loss imposes a financial impact since frequent applications are costly and labour intensive. Therefore, investigations on proper fertiliser application in maintaining good soil pH, improving plant growth, and increasing crop yield from various plantations across Malaysia are of paramount importance. Meanwhile, limited agriculturalrelated studies about crop management in Malaysia have been done. This study presents a state-ofthe-art review of Malaysia's paddy, oil palm, pineapple plantations, and the existing nutrient management and fertilisation practices throughout the crop cycle. A systematic study of the existing crop management in terms of farming practices, nutrient management, and fertiliser application on the plantations of paddy, oil palm, and pineapple in Malaysia was carried out. Industry overviews for these three crop types based on past situations and future directions are also included. Recommendations on how to better manage these plantations are also outlined to promote a better understanding of the past, current, and future direction of the agricultural activities and management for principal edible crops like paddy, oil palm, and pineapple in Malaysia.
\end{abstract}

Keywords: Nutrients, Paddy, Oil Palm, Pineapple, Fertiliser.

\section{Introduction}

Some of the major agricultural activities in Malaysia are the plantations of paddy, oil palm, and pineapple. Rice supplies an essential food source for more than $50 \%$ of the world population [1]. The paddy production across the globe has shown an increasing yearly trend from 448.2 million metric tonnes in 2009 to 499.1 million metric tonnes in 2019 and this is crucial to fulfilling the demand of the increasing population [2]. Being one of the Asian countries that are highly dependent on rice as the source of carbohydrates, Malaysia must increase rice production to support its rising populations. For instance, in the year 2016, a total of 2.7 million metric tonnes of paddy were produced domestically in Malaysia, with an average yield of 4 metric tonnes per hectare (ha). There are about 44 varieties of rice that have been developed in Malaysia. Regardless of the rice varieties, the total domestic

\footnotetext{
* Corresponding author.

E-mail address: christineyeo@curtin.edu.my (Wan Sieng Yeo)
}

Manuscript History: Received 13 May, 2021, Revised 29 June, 2021, Accepted 30 June, 2021, Published 31 October, 2021 Copyright (C) 2021 UNIMAS Publisher. This is an open access article under the CC BY-NC-SA 4.0 license. https://doi.org/10.33736/jaspe.3438.2021

e-ISSN: 2289-7771

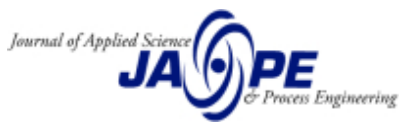


production increases moderately along with a quicker consumption rate. Realizing the fact that the consumption rate outstrips the production rate, rice is imported to Malaysia every year to narrow down the gap. Generally, there are two types of paddy in Malaysia, namely hill paddy and wet paddy. Regardless of the paddy types, the effort to change from agriculture that relies solely on soil fertility to agriculture that is dependent on fertiliser must be made. An appropriate fertiliser application is a crucial factor that must be taken to improve soil fertility and rice crop yield [3].

Other than the paddy industry, the oil palm industry is considered as one of the major contributors to Malaysia's gross domestic product of the agriculture sector in the year 2018. There are about 2.3 billion people in the world that depend on oil palm as a necessity. Around 5.74 million ha of land in Malaysia were under oil palm cultivation, which was estimated to produce 86.33 million tonnes of fresh fruit bunches (FFB) and 17.32 million tonnes of crude palm oil (CPO) in the year 2016 [4]. In South-East Asia, millions of people are working in oil palm agriculture [5]. Fertiliser application is crucial in the Malaysian oil palm industry as it plays a major role in improving growth and yields to get favourable conditions [6].

The trend of the area planted with oil palm in Malaysia is estimated to be increasing due to the agricultural policies implemented by the government. As of December 2019, the total area planted with oil palm trees in peninsular Malaysia and East Malaysia is 2,769,003 hectares $(46.9 \%)$ and $3,131,154$ hectares (53.1\%), respectively [7]. Additionally, the distribution of planted area owned by private estates, government schemes, state schemes and independent smallholders were 3,508,554 (61.2\%), 951,169 (16.5\%), 344,314 (6\%), and 933,948 (16.3\%), respectively [8]. The oil palm activities are scattered and located in the whole of Malaysia as well as involving different distributors in which private sectors have the biggest area of oil palm plantation.

The expansion of the planted area leads to a rapid increase in the volume of CPO and FFB. Abdullah [9] stated that CPO production is heavily affected by the number of mature oil palm trees, replantation, and FFB yield as it has become one of the major agricultural commodities. Other than that, external factors such as the environment and natural phenomena have a significant impact on the industry. FFB production fluctuates due to El Nino and La Nina. As a result, a decrease of $2.2 \%$ and $3.1 \%$ was recorded in 2009 and 2010 respectively. In the year 2016, the FFB production was estimated to be around 86.3 million tonnes [8].

Apart from paddy as the important food crop and oil palm as the essential commercial oilseed crop in Malaysia, the production of pineapple as one of the valuable tropical fruits in Malaysia increased from 244,353 tonnes in the year 2013 to 340,721 tonnes in the year 2017, an increment of $39.4 \%$ due to expansion of crop area in the country. As of the year 2017, the pineapple had about $12,898.44$ ha, which is equivalent to approximately $7 \%$ of the overall area planted with other tropical fruits [10]. In terms of production capacity, the pineapple emerges as the second-highest, behind banana production. The abundant use of fertilisers in today's world is inevitable in promoting the growth of crops and fruits. For the pineapple industry, Nitrogen, Phosphorus, and Potassium (NPK) are widely used with intense research carried out worldwide on the effects of the nutrient conditions on the pineapples [11].

The objective of this review is to present a systematic study of the existing crop management in terms of farming practices, nutrient management, and fertiliser application on the plantations of paddy, oil palm, and pineapple in Malaysia. Industry overviews for these three crop types based on the past situation and future direction are also included. This review paper is significant as there are limited agricultural-related studies relating to crop management available in Malaysia. Thus, this effort could promote a better understanding of the past, current, and future direction of the agricultural activities and management for principal edible crops like paddy, oil palm and pineapple in Malaysia. The review starts with an introduction to fertilisers and soils, followed by the management of paddy, oil palm, and pineapple, and lastly, ends with a summary and recommendations.

e-ISSN: 2289-7771

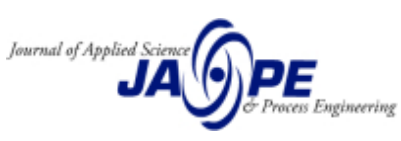




\section{Fertilisers and soils}

\subsection{Global and domestic fertiliser consumption}

The fertiliser price level has a deep impact on crop production. It is reported that the agricultural sector grew at a significant rate of 5.1\% annually [12]. The research conducted by Rehman et al. [12] also stated that the Asia Pacific region took $60 \%$ of the share market in the year 2018. Some of the challenges faced by the fertiliser industry are volatility in energy prices and need for nutrients, low agricultural commodity prices, strong competitors, and, lastly, soft global trade. It is also found out that some of the innovations used to produce better eco-friendly fertiliser were stunted due to cost and environmental regulations. It can be observed that the macronutrient levels increase and this increase is due to the rising human population and demand for food [10]. As a result, the consumption of fertiliser in the agricultural industry continues to increase.

According to the Food and Agriculture Organization of the United Nations [13], the world consumption of macronutrients such as $\mathrm{N}, \mathrm{P}$ and $\mathrm{K}$ is predicted to increase from 185 million tonnes in the year 2014 to 187 million tonnes in the year 2015. As calculated with successive growth of $1.6 \%$ per annum, it is speculated that it would reach 199 million tonnes in the year 2019 [13]. Meanwhile, for the East Asia region including Malaysia and neighbouring countries, the compound annual growth rate is expected to range from $0.41 \%$ to $1.44 \%$ for all macronutrients. In East Asia, the $\mathrm{N}$ consumption was predicted to increase from 43,398 thousand tonnes in the year 2014 to 44,970 thousand tonnes in the year 2019 [13]. For P consumption, the increment was predicted from 14,792 thousand tonnes in the year 2014 to 15,040 thousand tonnes in the year 2019. Lastly, the K consumption was expected to increase from 12,097 thousand tonnes in the year 2014 to 15,040 thousand tonnes in the year 2019.

\subsection{Types of fertiliser}

Based on the research conducted by Trenkel [14], there are three common classifications of fertiliser used globally, namely, slow-release fertiliser, controlled-release fertiliser and supergranulated fertilisers. The first classification is slow-release fertilisers from condensation products. Currently, there are different types of slow-release fertilisers that have been developed. These fertilisers are designed to address the limitation of conventional fertilisers that are lost to the ground easily due to surface runoff, leaching, and volatilisation. Urea-formaldehyde ( $38 \%$ of $\mathrm{N}$ ), ureaisobutyraldehyde $(32 \%$ of $\mathrm{N})$ and cyclo diurea $(32.5 \%$ of $\mathrm{N})$ are commonly used by farmers. Morgan et al. [15] found out that slow-release, controlled-release, and super-granulated fertilisers were used for non-farm usages such as landscaping and nurseries.

The second classification is called controlled-release fertilisers, whereby these fertilisers are coated or encapsulated with organic or inorganic materials. The coating gives a lower dissolution rate and longer duration release. Under this classification, three typical coatings have been used to control the perforation of water. The first type of control-release fertiliser is sulphur-coated urea (SCU). The sulphur acts as a waterproof layer, which is steadily deteriorating via microbial activities, chemical processes, and physical changes. The dissolution of urea in the SCU started with microbial activities and was followed by the breaking down of the sulphur coating via hydrolysis reaction [14]. Secondly, it is using polymeric or polyolefin materials as coating or capsule's shell. Coatings for polymer can be made of impassable or semi-passable barriers with small pores surrounding them.

The third coating type combines sulphur and polymeric material as a membrane or capsule's shell. Simonne and Hutchinson [16] asserted that coatings are able to reduce the rate of water penetration. Thus, it helps control the release rate of N, P, K, and other micronutrients into the soil. Apart from that, these hybrid coatings can reduce the burdens faced by farmers due to lower input cost. The third classification is super-granulated fertilisers and others. Its application in tropical and

e-ISSN: 2289-7771

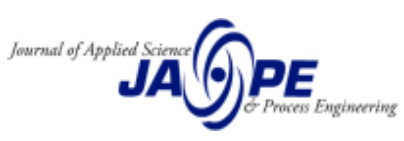


subtropical areas drew attention to the manufacturers in the agricultural industry. By formulating the standard soluble fertilisers in the compacted form, it has a slower release rate of nutrients into the soil solution compared to standard soluble fertiliser.

\subsection{Mulder's chart for nutrient-nutrient interactions}

Chemical fertilisers are usually formulated based on different compositions of NPK, and with a small amount of other minor nutrients such as magnesium and sulphur. Besides, different plants require a different level of NPK and therefore, a field test is necessary to determine the correct amount. The reason being, imbalanced NPK levels may affect the productivity of the soil [17]. Also, excess fertiliser can cause a reduction of useful microbial communities and contamination of underground water. Effective nutrient management is also important due to nutrient-nutrient interactions. According to Fageria [18], it is a condition when the supply of one nutrient affects the absorption and utilization of the other nutrients into the plant. It has commonly occurred in the growth medium when the concentration of one of the available nutrients is in excess [19]. This relationship can be represented by Mulder's chart which simplifies the understanding of interactions that occurs between various plant nutrients [20]. More details about each plants nutrients were studied by Lai et al. [21].

\subsection{Bacteria in the soils}

Besides fertilisers, microbial activity in the soil also plays a significant role in promoting plant growth. According to Glick [22], the soil is a habitat for a variety of microorganisms such as bacteria, fungi, protozoa, and algae. The motivation for the rising interest in microbial analysis is due to its potential as a plant growth regulator [23]. Meanwhile, chemical fertiliser and pesticides are being widely used to promote paddy growth. Research done by Doni et al. [24] discovered that paddy growth can also be improved by using beneficial bacteria such as the plant growth-promoting rhizobacteria (PGPR). PGPR can be found in the thin zone of soil surrounding the root zone called the rhizosphere [25]. Aside from promoting healthy plant growth, these microorganisms are also able to increase the efficiency of fertilisers, root biomass, and area, which indirectly enhance the plant's nutrient uptake capacity [26]. Furthermore, Mhatre et al. [27] reported that some beneficial bacteria have an antagonistic action against pathogens or Plant-Parasitic Nematodes (PPN).

Table 1 summarises some examples of PGPR and fungi with their roles. From Table 1, it can be seen that different PGPR have different roles in controlling the growth performance of the paddy plant. So, this shows that it is good to have various PGPR communities present in the soil. As can be seen from Table 1, bacteria also play an important role in the soil's nutrient availability [28]. Nutrients in the soil need to be retained in the soil when crops die or used up to allow the soil to have enough nutrients for further life to grow. These nutrients are recycled via ground detritus, ingested pant matter or faeces as well as soluble organic products from the roots. It is also found that the root exudates and the detritus contain lots of nutrients and are both sources of energy for numerous bacteria and microbial communities. The soil bacteria vary from place to place based on the geographical nature of the place as well as the various factors, including $\mathrm{pH}$ of the soil and temperature and therefore should be studied independently.

One of the methods used to identify bacteria in the soils is using the Grams staining method that classifies these bacteria as either Gram-positive or Gram-negative. This method was identified by Hans Christian Gram, which uses the reactions of the bacteria's cell wall to certain dyes [29]. In Grampositive bacteria, their cell walls are made of peptidoglycan or murein. Gram-negative bacteria have a much thinner layer of peptodologyen and do not include the lipopolysaccharide in their outer membrane. The gram staining method uses slides that are stained with crystal violet and iodine. They are then de-stained with alcohol and counterstained with safranin. Based on these results, gram-

e-ISSN: 2289-7771

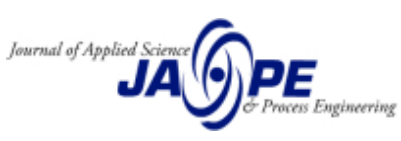


positive and gram-negative bacteria will stain purple and reddish pink, respectively [29]. This method of classification has been used for numerous years and relies on the principles of observation that the organism can be identified.

Table 1. Plant growth-promoting Rhizobacteria and its role in paddy plantation.

\begin{tabular}{c|c|c}
\hline PGPR & Role/Effect produced & Reference \\
\hline Azobacter & $\begin{array}{c}\text { Transport iron into plant cells aiming for better } \\
\text { growth promotion }\end{array}$ & {$[30]$} \\
\hline Azospirilium & Enhance rice yield components & {$[31]$} \\
\hline Bacillus sp. & Suppress PPN and promote plant growth & {$[32]$} \\
\hline $\begin{array}{c}\text { Enterobacter, Erwinia, } \\
\text { Flavobacterium }\end{array}$ & Act as phosphate solubilizers & {$[33]$} \\
\hline Pseudomonas sp. & A dominant antagonist of PPN & {$[34]$} \\
\hline Trichoderma virens (fungi) & $\begin{array}{c}\text { Effect on germination, root and shoot length, } \\
\text { grain weight }\end{array}$ & {$[35]$} \\
\hline $\begin{array}{c}\text { T. ghanense (fungi) } \\
\text { variety }\end{array}$ & Promote the seedling growth of aerobic rice \\
\hline $\begin{array}{c}\text { CandidatropicalisHY (CtHY) } \\
\text { (fungi) }\end{array}$ & Stimulate the growth of rice seedlings. & {$[36]$} \\
\hline
\end{tabular}

\section{Paddy management}

\subsection{Varieties of paddy in Malaysia}

Generally, there are two main types of rice cultivated in Malaysia, namely wetland rice and upland rice [38]. There is no definite amount of rice varieties in Malaysia due to the continuous effort to develop a new rice seed with a high yield and resistance towards disease. According to Nazuri and Man [39], the seed research program is handled by the Malaysian Agriculture Research and Development Institute (MARDI). Considering only the breed rice varieties released by MARDI, the total rice varieties in Malaysia are 43 [40]. For instance, in the year 2001, the MR219 breed, which is one of the rice varieties, was declared to be the most popular rice variety grown by the local farmers in Malaysia due to its ability to improve rice crop yield up to 10.7 metric tonnes per ha [41]. In the year 2010, another new breed, namely MR220CL2 was developed and instantly became well known among the farmers due to its better performance. For the traditional rice varieties, it is estimated to be not fewer than 300 varieties in Sarawak. Different rice varieties have different characteristics, such as diverse grain shape, aroma, colour, and texture. As mentioned in the previous subtopic, the most famous rice varieties are Bario, Bajong, and Biris. Similarly, Sabah also has a diverse variety of traditional rice. Tzyy Jiann Chong et al. [42] identified 22 different Sabah traditional rice varieties in their research. Sulug, Wangi Keladi, and Belinda are a few examples of common traditional rice varieties in Sabah, Malaysia.

\subsection{Genetic analysis of paddy on the height, leaf size, and roots}

Over the decades, there have been numerous rice genetics studies carried out by researchers. Genetic analysis is essential for the future breeding of rice [43]. Normally, genetic studies involved the analysis of rice height, leaf size, and roots. Hybrid rice has better characteristics and improved 
qualities such as larger grain size, higher growth performance, yield, and better resistance to pests and disease [44].

According to Confalonieri et al. [45], the height of paddy can be used to estimate the potential crop yield provided that the accurate technique is used. Meanwhile, the height of rice crops is measured by a field survey [46]. Biologically, the height of the plant changes due to the expansion and elongation of its cell wall [47]. A few factors that affect cell expansion are conditions of the environment and the plant hormones themselves. In paddy cultivation, it is essential to achieve the optimum height of the plants. If it is too short, it may lead to insufficient growth, affecting the rice yield. On the other hand, if it is too tall, it may cause rice lodging, which will make the harvesting of rice difficult [48]. However, there is no optimum rice height that has been declared as it varies depending on the rice varieties [49].

Leaf size is a crucial component of the plant since it is where photosynthesis occurs [50]. It is a process where plants utilize sunlight, water, carbon dioxide, and nutrients to make food for growth [51]. Not only does it play a major role in photosynthesis, but it is also a major factor that determines the overall architecture of the plant and strongly affects crop yields [52]. Genetically, the leaf shape is controlled by quantitative trait loci. The shape itself is determined by many traits such as leaf length, width, area, and angle. According to Yang et al. [53], all these traits correspond to each other. For instance, the area of the leaf is greatly impacted by its length and width. The leaf angle is also determined by the leaf flag's length, where leaf drooping will happen if the length is too long. It has been also concluded that a small leaf angle is better as it promotes better distribution of light for photosynthesis [54].

The rice root system plays an important role in controlling the uptake of water and nutrients from the soil to support plant growth [55]. It is also essential to provide mechanical support to the plant. Research by Qu et al. [56] concluded that a strong root system, especially traits such as its length and thickness, is positively correlated to drought resistance. Besides, Zhao et al. [57] found that these traits also enable the paddy plant to survive under nutrient deficiency conditions.

\subsection{Cultivation method in paddy plantation}

According to Chen et al. [58], there are two rice cultivation methods: the transplanting and the direct seeding methods. The cultivation method used may depend on the availability of the workforce and technology. In Malaysia, both methods are still being used by local farmers. The traditional method of cultivating rice is through the transplanting method. A few stages involved in this method are raising nurseries, uprooting, picking seedlings, and transplanting to the field [59]. The transplanting method can promote stable yield and give the crop ahead starts over emerging weeds in the field, however, it is very laborious and expensive [60]. This argument is further strengthened by Ali et al. [61] that the urbanization in recent years has caused most of the labourers to move to other non-agricultural industries. As a result, labour cost becomes higher in the country.

For the past few decades, the cultivation method has been slowly shifting to the direct seeding method, which is more comfortable and convenient. According to Marasini et al. [62], three principal methods of direct seeding are dry, wet, and water seedings. Dry seeding is the sowing of dry seeds directly into dry soil, wet seeding is the sowing of pre-germinated seeds on wet puddle soils, and water seeding involves sowing seeds into standing water [63]. Direct seeding reduces cost and workforce, as well as promoting stable rice growth [64].

\subsection{Crop management strategies in paddy plantation}

In the past, the maximum rice crop yield in China was achieved through the application of integrated crop management. According to Peng et al. [65], plant and canopy morphological parameters have been developed by scientists in the province of Jiangsu of China to increase the crop

e-ISSN: 2289-7771

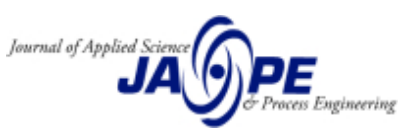


yield. This was developed to provide a guide for effective crop management at different growth stages of the paddy plant. There was also an attempt to breed super rice or super hybrid rice by combining interspecific heterosis with ideal plant types [66]. This was a successful effort as they managed to increase the overall grain yield. However, their impacts on a certain aspects, such as socioeconomic and environmental, were not adequately addressed. For each technology and alternative that have been invented, it was found that the integration among a few critical components of crop management practice, such as the synergy between fertiliser, water, soil, and pest management, was not properly examined. Evaluating the effectiveness of the new technologies based on its positive impacts on farmers' profit and yield was a huge mistake. Environmental impacts should also be considered. In fact, the sustainability of the rice production system can only be maintained and maximized if only the natural resources and the ecosystem is protected.

Therefore, realizing the fact that effective and successful implementation of various technologies cannot be measured solely based on the economic gains, four major elements have been considered as part of the paddy crop management strategy in this research. They are farming practices used by farmers, water source management, soil management, and effective environmental sustainability strategy in paddy cultivation. Each of these aspects is elaborated in detail as followed.

According to Wang et al. [67], farming practices such as the method of cultivation, seeds quality used in the cultivation process, and several plantation cycles per year could greatly affect the crop yield. In some countries such as Malaysia and Thailand, cultivation may occur for two cycles in a year, depending on the climate. For instance, in some of the subtropical regions in China, rice cropping will usually occur between April to July for the first cycle, and July to October for the second cycle [68]. Ray and Foley [69] also stated that the double seasons' rice system contributes to a higher multiple cropping index, which could increase the rice supply. However, despite being able to increase rice production, the limitation of this double seasons farming is that it cannot be implemented in a non-subtropical environment like Malaysia.

In rice cultivation, water is an essential need as it supports the plant's growth and development [70]. According to Bouman [71], water is used for the transpiration process in the rice plant system and to carry essential nutrients from roots to leaves. Usually, the paddy plant requires up to three times more water than other cereal plants to produce 1 kilogram $(\mathrm{kg})$ of rice grain [72]. Water is usually supplied manually by farmers or naturally by rain. However, rapid industrialization and climate change in a certain region have caused the water supply to be scarce. Tuong and Bouman [73] estimated that up to 20 million ha of irrigated rice, especially in Asia, may suffer water deficiency by the year 2025. Therefore, efforts to improve the available water supply technology in paddy plantations must be taken, so that rice can be produced to meet the demand of the rising population.

According to Chen [74], it is necessary to study the soil and nutrient variations within a field. The research also concluded that a soil-yield interrelationship must be established. Soil management is one of the crucial components that determine the productivity of the crop [75]. Here, soil analysis plays a major role in understanding the condition of the soil in the field. The study usually includes a microbe analysis and a soil $\mathrm{pH}$ test. The microbe analysis is conducted to identify the beneficial bacteria population level in the soil [76]. On the other hand, the soil $\mathrm{pH}$ is determined by the content of Hydrogen ions present in the soil and can be managed by the addition of amendments and fertilization [77]. For soil $\mathrm{pH}$, the favourable soil $\mathrm{pH}$ for the growth of the rice plant is between $\mathrm{pH} 5.5$ to $\mathrm{pH} 7$ [78].

Besides focusing on maximising profits and production, effective crop management should also emphasize environmental sustainability [79]. It involves the effort to preserve the environment to achieve both economic and agricultural goals without affecting the natural resources and the quality of the environment. Farmers often use pesticides to control pests and fertilisers to increase their crop yield. Excessive use of these chemicals may harm the environment. For instance, the uncontrolled application of fertiliser not only degrades the soil quality but will also cause major environmental

e-ISSN: 2289-7771

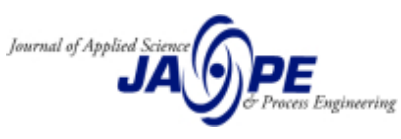


issues such as eutrophication [80]. As for the effect of pesticides, overdoses to the plant may lead to a high amount of residue in the food [81].

Therefore, it is recommended that the research and development program must be conducted to determine the adequate number of pesticides and fertilisers that should be applied in different paddy plants. Another way is by practising biological control to control pests in the paddy field ecosystem [82]. Aside from being environmentally friendly, it is also relatively cheap and reliable because the concept uses other living organisms instead of chemicals to control pest populations [83].

\subsection{Factors affecting paddy growth}

Many factors affect the performance of paddy growth, including the type of soil. This is important as the type of soil may affect the root systems of the paddy plant. In addition, another factor that will be discussed in this section is climate change. A few climatic factors such as temperature, humidity, and rainfall rate have a major role in influencing the growth performance of the paddy plant. Besides, other factors affecting paddy growth, which will be elaborated in detail under this subtopic, are microbial activity and effective nutrient management.

Dou et al. [84] reported that rice production could be significantly affected by soil texture. The reason being different soil textures will have different soil available water capacities (AWC). For example, Six et al. [85] mentioned that more organic matter is content in clay soil compared to sandy soil. Organic matter is directly proportional to AWC, which means the higher the content of the organic matter, the higher the AWC. In this case, clay soil has a better performance than sandy soil due to its water content. Besides, the soil type influences the plant's root growth. As suggested by Smith and De Smet [86], the root system is important to any type of plant due to its function in supporting various biological processes in the plant and acts as the major interface between the plants with the soil environment. McMichael and Quisenberry [87] stated that among the soil properties that impact the development of root systems are the soil's strength, temperature, composition, and water content. Usually, long and dense root systems are better because they could enhance water and nutrient uptake to support paddy growth [88].

According to Alam et al. [89], paddy production in Malaysia is highly influenced by variations of climate factors. Some of the climatic parameters that could affect the growth of rice are temperature and humidity. Temperature ranges from $27^{\circ} \mathrm{C}$ to $32^{\circ} \mathrm{C}$ is the most optimum temperature range for the development of the paddy plant [90]. At the same time, the optimum relative humidity lies between $60 \%$ to $80 \%$. In Malaysia, the average temperature is $26.7^{\circ} \mathrm{C}$ with an average humidity of $74 \%$ to $86 \%$ every year [91]. Based on these statistics, Malaysia has yet to be affected by climate change. Other than that, Yan et al. [92] also found that rainfall could affect the rice yield. Excessive rainfall may cause floods which can damage crops and land fertility. Despite this, it will affect crop productivity, but farmers may also experience economic losses from natural disasters. As mitigation steps alone are not sufficient, the balance between measures against the factors contributing to climate change and measures to deal with its adverse effects must be established. In addition, Ko et al. [93] also suggested the effort to implement alternative management practices such as using new crop genotypes that could easily adapt to the world climate's future changes and should be made to sustain the rice production.

Finally, through an effective nutrient management strategy, it has been proven that fertilization plays a vital role in improving soil fertility and rice yield [94]. A research study conducted by Masni and Wasli [95] had found that a proper application of fertiliser with adequate rate and timing can increase the rice yield and influence the production cost. Fertilisers can be classified into organic or inorganic fertilisers, and according to Han et al. [96], organic fertilisers are usually produced from animal by-products while inorganic fertiliser is chemically formulated through research. Table 2 summarises the pros and cons of these fertilisers. It is found that inorganic or chemical fertilisers will have more negative impacts on the environment. Organic fertilisers, on the other hand, have better

e-ISSN: 2289-7771

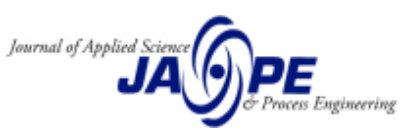


tolerance towards the environment. The main issue with this type of fertiliser is that it has low nutrient content, which may be insufficient to support the growth of some types of paddy plants.

Table 2. Pros and cons of organic and chemical fertilisers.

\begin{tabular}{|c|c|c|}
\hline $\begin{array}{c}\text { Type of } \\
\text { fertilisers }\end{array}$ & Pros & Cons \\
\hline Organic & $\begin{array}{l}\text { - Cost-effective and ecologically } \\
\text { friendly [97] } \\
\text { - It has a better tolerance with the soil } \\
\text { microbes [98] } \\
\text { - Able to alleviate acidification of soil } \\
\text { [99] }\end{array}$ & $\begin{array}{l}\text { Low nutrient content, slow } \\
\text { decomposition, and different } \\
\text { amount of nutrients composition } \\
\text { depending on its organic } \\
\text { materials }\end{array}$ \\
\hline $\begin{array}{l}\text { Inorganic } \\
\text { (chemical) }\end{array}$ & $\begin{array}{l}\text { Dissolves quickly especially in damp } \\
\text { soil [100] } \\
\text { Better performance in enhancing the } \\
\text { growth rate and the plant's overall } \\
\text { productivity [101] } \\
\text { It contains enough primary and } \\
\text { secondary nutrients that can raise soil } \\
\text { fertility. } \\
\text { - Promotes better improvement in crop } \\
\text { yield [102] }\end{array}$ & $\begin{array}{l}\text { - } \text { More expensive cost [103] } \\
\text { Excessive use may lead to soil } \\
\text { acidification and nutritional } \\
\text { imbalance } \\
\text { - May cause environmental issues } \\
\text { such as water pollution and } \\
\text { eutrophication } \\
\text { - Reduce soil microbes' } \\
\text { population [104] }\end{array}$ \\
\hline
\end{tabular}

\section{Oil palm management}

\subsection{Overview of the oil palm industry}

The worldwide oil palm production is steadily growing, and the targeted production for this year would be around 73.5 million metric tonnes in the years 2018 and 2019 market [105]. Currently, the leading worldwide exporters are from Indonesia and Malaysia, with approximately $90 \%$ of the global output. Indonesia received certification from Roundtable on Sustainable Palm Oil, around 20\% of the global oil palm production in the year 2017 [106]. The production level in the years 2015 and 2016 slightly dropped because of El Nino [105]. This phenomenon affected the whole world by shifting in the winds and water current across the equatorial Pacific. In July 2019, data from MPOB also reported that around 1,740 tonnes per month of crude palm oil were obtained, which increased from 1,510 tonnes per month in June 2019. The highest record obtained was in August 2015 with 2,051 tonnes per month [107]. Inversely, the lowest record obtained was in January 1988 with 265 tonnes per month. With the difference of about 30 years, the curve of growth illustrates a positive development.

\subsection{Effective management of soil and fertiliser in oil palm plantation}

With the implementation of good soil management practices, the soils can sustain the nutrients and continuously supply the oil palm trees for over 75 years. Goh et al. [108] proved that poor soil management practices lead to severe impacts on the production of FFB and growth. The research was conducted at Rengam, Johor and Selangor. The respective oil palm plantation was able to yield 15 and 32 tonnes of FFB per ha in a year. With the presence of organic fertiliser, the yield of the FFB is the same for both plantation sites. By manipulating the marginal land, many farmers are now able to cultivate oil palm trees, exploiting the soil potentials. Thus, it helps to create strong competition among suppliers and stimulate economic feasibility.

e-ISSN: 2289-7771

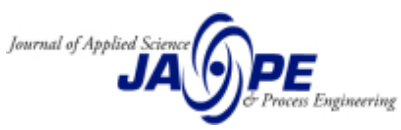


Different soils need different conditions to unlock their full potential in maximizing the production yield. Pretty and Sanders [109] discovered that soil utilization is at the highest if soil management practices, external factors and internal factors are taken together into account. Lack of land for food cultivation is one reason that soil management practices are needed to fulfil and satisfy the demand and growing human population. Thus, it helps to exploit the soil potential by changing the soil conditions. Another critical parameter that needs to be considered in the fertiliser management system in an oil palm plantation is growth and yield. This is carried out by measuring the growth rate and analysing the yield trend before and after the application of fertiliser. Additionally, some of the objectives of fertiliser management are to provide enough nutrients in equivalent fraction to give the optimum yield of FFB and standard growth curve for each palm, to apply proper and recommended amount of fertiliser to give the optimum nutrients uptake based on the areas' conditions, and to assimilate the application of palm residues and mineral fertilisers.

\subsection{Nutrient losses in oil palm plantation}

In the oil palm plantation, nutrient losses may occur in various ways. Firstly, the nutrient may be lost through surface runoff. Surface runoff is due to the quantity of water received from rainfall and runoff gained from higher altitudes that flow over the land surface without permeating the soils. Compacted soils and scattered vegetation are more susceptible to surface runoff. Maene et al. [110] conducted a study on 10 years old oil palms in West Sumatra. It was found out that there was valuable information in spatial variability when the researcher compared the soil water infiltration rates in palm path, circle, and frond stack as the infiltration rate increased from the path, circle, and frond stack, respectively. Table 3 shows the nutrients losses caused by surface runoff as evidence that surface runoff is a concerning issue to the developers and farmers.

Aside from the surface runoff, the nutrient loss could occur via leaching. Leaching losses can be defined as the translocation of soluble nutrients from the soil into the drainage water as it passes through the soil profile. This factor could be a serious matter, especially on coarse-textured soils if the rainfall surpasses the evapotranspiration. Rashmi et al. [111] stated that some of the important parameters affecting the leaching losses are type, available nutrient content, amount and intensity of rainfall or irrigation water, the nature of the crop plant or extent of the soil surface covered by it. The researcher conducted an oil palm lysimeter study on early-stage oil palm trees, which was during the first four years of the oil palm tree's life, and found out that around $70 \%$ of Magnesium $(\mathrm{Mg}), 17 \%$ of $\mathrm{N}, 2 \%$ of $\mathrm{P}$ and $10 \%$ of $\mathrm{K}$ were lost due to leaching. However, the losses were reduced significantly when the oil palm trees entered their maturity phase. Some of the contributing factors to high losses during the early stage were low extensive root system, not well-established ground covers, and poor palm canopy cover.

Table 3. Average nutrient losses via surface runoff [110].

\begin{tabular}{c|c|c|c|c|cc}
\hline \multirow{2}{*}{ Area } & \multicolumn{7}{|c}{ Percentage of Losses (\%) } \\
\cline { 2 - 7 } & N & P & K & Mg & Calcium & Boron \\
\hline Oil palm row & 13.3 & 3.5 & 6 & 7.5 & 6.8 & 22.9 \\
\hline Harvest path & 15.6 & 3.4 & 7.3 & 4.5 & 6.2 & 33.8 \\
\hline Pruned frond row & 2 & 0.6 & 0.8 & 2.7 & 0.8 & 3.3 \\
\hline $\begin{array}{c}\text { Pruned } \\
\text { frond/harvest path }\end{array}$ & 6.6 & 1.4 & 3.5 & 2.2 & 3.4 & 12.5 \\
\hline $\begin{array}{c}\text { Nutrients applied } \\
\text { (kg/ha) }\end{array}$ & 90.2 & 52 & 205.9 & 32.8 & 78.9 & 2.4 \\
\hline
\end{tabular}

e-ISSN: 2289-7771

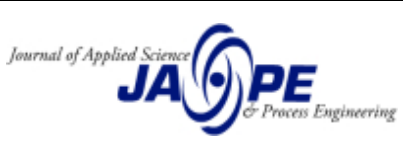




\subsection{Environmental effect of over fertilisation in oil palm industry}

Over fertilisation is a condition when there is an excessive amount of fertiliser used in agricultural activities. As a result, there is an increment in the concentration of NPK in the soil. Luo et al. [112] reported that heavy rainfall and irrigation are some of the main contributing factors of fertiliser dissolution, where it percolates the excess nitrate fertiliser. Thus, it causes the waterways such as rivers and seas to undergo hypoxia or lack of dissolved oxygen. A high concentration of nitrates also leads to algae bloom and a source of nitrate poisoning to warm-blooded animals. Other side effects found in a study conducted by Howarth et al. [113] are excessive N are eutrophication, increment in $\mathrm{pH}$ of soils and waters, biodiversity loss, especially from the aquatic ecosystem, and increment of greenhouse gases. One of the most significant greenhouse gases is nitrous oxide, which helps to fasten up global warming and the thinning of the ozone layer. Other than that, building up of $\mathrm{K}$ in the soils potentially could cause the salt formation and modification of soil structure.

\section{Pineapple management}

\subsection{Overview of the pineapple industry}

Pineapples (Ananas comosus [L.] Merr.) are a tropical fruit that is one of the highest produced tropical fruits worldwide and are usually grown in tropical climates and areas [114]. Pineapples come in various forms, and several types are cultivated worldwide more than others. These are Millie Dillard (MD2), Smooth Cayenne, Singapore Canning, Queen, Perola, Manzana, Perolera and Espanola Roja. Of all these types the most planted cultivator worldwide is the Smooth Cayenne due to its high yields, shapes, and taste, making it ideal for canning [115]. In Malaysia, 9 major varieties are currently grown. These are mostly Moris, N36, Sarawak, Moris Gajah, Gandul, Yankee, Josapine, Masapine, and MD2. As of the year 2018, total pineapple exports totalled a massive US\$2.12 billion, with an increase of about $4.3 \%$ from the year 2017 [116]. Malaysia is one of the countries that export pineapples accounting for $0.3 \%$ of the world's total exports. There is a range of different types of pineapples, with the MD2 pineapple specifically chosen in Malaysia to be promoted for industrial planting. This is identified by the Malaysian Pineapple Industry Board as a key fruit, therefore helping in penetrating markets and in increasing economic growth [11]. The main types of pineapple are Smooth Cayenne, Queen, Red Spanish, and MD-2 [117].

Pineapples contain sugars and are generally acidic. It is balanced between the sugar to acid ratio that helps determine the pineapple's use, i.e., canned, fresh, or as juice. The citrus acidity provides a sourness to the pineapples and, hence, is generally related to the acid content and sweetness of the pineapple [118]. The lower the acidity, the greater the sweetness and this is used to compare the sweetness of the pineapples under the various fertiliser types. To test the acidity, a simple titration procedure is carried out to determine the percentage of acid in the pineapple. The pineapple mixture is titrated against a simple base such as sodium hydroxide with indicators placed inside. This acid-base reaction shown in Equation (1) creates a colour change in the indictor when neutralisation is reached between the acid and base. The reaction is represented by Equation (1) and is used to determine the amount of acid percentage in the specific volume of blended pineapple. Simple mathematics can then be used to determine this, and the method has previously been shown to be successful.

Total Acid in Pineapple + Sodium Hydroxide $\rightarrow$ Salt + water

\subsection{Nutrient management in the pineapple industry}

Plants require numerous nutrients to thrive, more so in pineapples. They require various nutrients to allow for proper growth, and these must be provided in specific quantities, with each

e-ISSN: 2289-7771

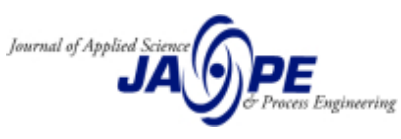


nutrient factoring in the growth in its unique way [119]. NPK plays a big role in maintaining a healthy life for these fruits. Peat soils or more commonly defined as organic soils contain mostly organic matter, which means they have higher nutrient content and the peat soils of Sarawak tend to be acidic with low amounts of $\mathrm{N}$ in the shallow layers of the soil [119]. This means fertilisers are provided to enhance growth because organic materials alone are not sufficient to keep growing large quantities of pineapple constantly.

Three main elements used by the plants and those in the fertilisers are NPK. Plants mainly use $\mathrm{N}$ during the process of photosynthesis as it is a key component in chlorophyll. It is used when proteins for plants need to be made. Research into the effect of $\mathrm{N}$ on the growth of pineapples was carried out by Spironello et al. [120] whereby an experiment was carried out in Sao Paulo, Brazil where $\mathrm{N}$ was applied alongside Potassium Oxide $\left(\mathrm{K}_{2} \mathrm{O}\right)$ in amounts of $0,175,350$, and $700 \mathrm{~kg}$ per ha mainly applied as urea and potassium chloride $(\mathrm{KCl})$. They were applied in 4 splits of $11.4 \%, 17.1 \%$, $28.6 \%$, and $42.9 \%$, respectively, at one, six, eight, and ten months after planting (MAP). The results showed that at $0 \mathrm{~kg}$ per ha of $\mathrm{N}$ applied, the least yield of pineapple was recorded, thereby agreeing with the theory that $\mathrm{N}$ is an important component for improving pineapple growth.

It also concluded that the increase in $\mathrm{N}$ did result in heavier fruits and larger yields, however, the quality of the fruits was affected as the total titratable acidity, and total soluble solids (TSS) were reduced. The best amount of $\mathrm{N}$ alongside $\mathrm{K}_{2} \mathrm{O}$ was found to be 498 and $394 \mathrm{~kg}$ per ha. Additionally, Omotoso and Akinrinde [121] reported on the effect of $\mathrm{N}$ on pineapples in Nigeria. Their study showed that the treatments consisted of $\mathrm{N}$ applied at $0,50,100,150$, and $200 \mathrm{~kg}$ per ha. $\mathrm{N}$ was applied as urea and base doses of $\mathrm{P}$ of $50 \mathrm{~kg}$ Phosphorus Pentoxide $\left(\mathrm{P}_{2} \mathrm{O}_{5}\right)$ per ha and $\mathrm{K}$ at $100 \mathrm{~kg}$ per ha of $\mathrm{K}_{2} \mathrm{O}$ as $\mathrm{KCl}$ was given to all the plants. The $\mathrm{N}$ was applied in 3 doses at the beginning, after 3 months, and lastly at 6 months. The soil was a sandy loom and showed that it consisted of low $\mathrm{N}$ and available $\mathrm{P}$. The results were in line with these predictions as the production increased the pineapples' yield alongside the size; however, peak production was found at $150 \mathrm{~kg}$ per ha.

Besides, another important macronutrient needed by the pineapples to grow is $\mathrm{P}$. It is used by plants in an essential role in the root's development and the DNA of the plant. It is not as highly recommended to be used as compared to that of $\mathrm{N}$ and $\mathrm{K}$, however, it does have its effect. A research study that was done by Valleser [122] showed the effect of $\mathrm{P}$ and the experiment was carried out in Adtuyon clay soil in Bukidnon, Philippines. Smooth Cayenne Pineapple was used in this case as the pineapple of choice. It showed that the amount of $\mathrm{P}$ was varied and applied in 3 replications. The study consisted of a randomized complete block design with 5 variations of $\mathrm{P}$ as treatments, which were 0 , $84,127,169$, and $211 \mathrm{~kg}$ per ha, respectively [122]. These were applied separately apart from a blanket dose of $\mathrm{N}$ and $\mathrm{P}$ that were already applied. These results showed that the final pineapple plants with no $\mathrm{P}$ produced the smallest height than those that had. Larger fruits were also present in areas where 211 and $169 \mathrm{~kg}$ per ha were applied. The overall yield did not change much with the different rates of $\mathrm{P}$ applied. It is concluded that the $169 \mathrm{~kg}$ per ha produced the optimum fruit and yield for the soil in Philippines and showed that the amount of $\mathrm{P}$ did not directly relate to the MD2 pineapple.

On the other hand, $\mathrm{K}$ has a less direct role as it is usually used by plants to help activate its enzymes [123]. The effect of $K$ in fertilisers was studied by Teixeira et al. [124]. Teixeira et al. [124] highlighted the importance of $\mathrm{K}$ for plants and previous research that was done on the uptake of $\mathrm{K}$ as a fertiliser. It was seen that $\mathrm{KCl}$ was used before; however, it had largely been replaced in the industry due to being relatively easier to leach than other nutrients such as Potassium Sulphate $\left(\mathrm{K}_{2} \mathrm{SO}_{4}\right)$ or $\mathrm{K}_{2} \mathrm{O}$ [125]. This led to the investigation of the effect $\mathrm{K}$ had. The experiment was carried out in Brazil, whereby randomised block design was used for 4 rates of $0,175,350$, and $700 \mathrm{~kg}$ per ha of $\mathrm{K}_{2} \mathrm{O}$ and 3 other combinations were tried out. These combinations were $100 \%$ of $\mathrm{KCl}, 100 \%$ of $\mathrm{K}_{2} \mathrm{SO}_{4}$ and a mixture of $40 \%$ of $\mathrm{K}_{2} \mathrm{SO}_{4}$ and $60 \%$ of $\mathrm{KCl}$. Base application of $\mathrm{N}$ and $\mathrm{P}$ were applied in a one-off application of $80 \mathrm{~kg}$ per ha of $\mathrm{P}_{2} \mathrm{O}_{5}$ and $600 \mathrm{~kg}$ per ha of $\mathrm{N}$. The results from these showed that that irrespective of the $\mathrm{K}$ source, the uptake of $\mathrm{K}$ by plants was directly related to the amount of $\mathrm{K}$ in the soil and fertilisers. The results also disagreed with the previous theory that $\mathrm{KCl}$ was more viable for 
leaching. However, it did show that $\mathrm{KCl}$ as a choice could be avoided due to pineapples' sensitivity to chlorine in the soil unless proper management was taken. A range of $600 \mathrm{~kg}$ per ha was suggested for the pineapple crop in this region as the data was shown. Large $\mathrm{K}$ values did reduce the Calcium and $\mathrm{Mg}$ in the leaves, which may be explained by the competition between ions for transport sites in the roots' plasma membrane [126]. It did conclude that $\mathrm{K}$ was important and that either source would provide it as the changes amongst the different options were not relatively large.

Spironello et al. [120], Omotoso and Akinrinde [121], Valleser [122] and Teixeira et al. [124] reported that the application of NPK fertilisers enhanced growth in the majority of the cases. The different soil conditions, geographical locations, and pineapple types must be considered in these scenarios as they all differed from one another. Furthermore, they reported that high $\mathrm{N}$ and $\mathrm{K}$ mostly affected the yield with even base doses in other experiments that were of similar quantities. P, however, seemed to show not much change, although it was still critical in the analysis.

\subsection{Flower induction for the pineapples}

Flowering induction is the stage in plants whereby they change from the vegetative state to the reproductive state. It is influenced by various factors, including hormonal change, length of the day, and climatic factors [127]. Flower induction can occur naturally or be induced artificially. Natural flowering is a complex process that gives rise to various inconsistencies and issues. It is also stated that flowering will occur between various seasons, which gives loss to farmers worldwide. It is mostly caused when flowering is precocious and leads to difficulties as pineapple management is harder as production and harvesting dates cannot be determined. This also results in slower sales resulting in reduced incomes. Thereby, various studies are examined on artificial flower induction.

Turnbull et al. [128] investigated the effects of ethephon or 2-chloroethylpho-sphonic acid and ethylene $\left(\mathrm{C}_{2} \mathrm{H}_{4}\right)$ gas as they are considered the most frequently used chemicals in pineapple flowering induction. The study chose to compare 5 versions of these components mostly, Zeothene, ethephon, $\mathrm{C}_{2} \mathrm{H}_{4}$ dissolved in water, $\mathrm{C}_{2} \mathrm{H}_{4}$ dissolved in water with activated carbon, and lastly, commercial $\mathrm{C}_{2} \mathrm{H}_{4}$ gas. Zeothene is zeolite pearls loaded with pure $\mathrm{C}_{2} \mathrm{H}_{4}$ gas which is released upon contact with water. These agents were applied between 8 to 9 MAP based on the commercial induction periods used. Additionally, their study also sought to find the maturity stage for these MD2 pineapples by applying the inducing agent Zeothene at different levels of 1 to 8 MAP. These treatments were applied 3 times and were applied at the plant's central cup to increase effectiveness.

However, for the $\mathrm{C}_{2} \mathrm{H}_{4}$ gas field application, this was not the case as it was sprayed directly all over the plant using a pressurized sprayer. This was the usual flower induction method consisting of $2.272 \mathrm{~kg} \mathrm{C}_{2} \mathrm{H}_{4}$ gas sprayed with a mixture of 7,000 Litre (L) of water, and $20 \mathrm{~kg}$ activated carbon per ha. For the water-based solutions, they were created using Zeothene. Three different concentrations were made using 0.389 g $\mathrm{C}_{2} \mathrm{H}_{4}$ per $\mathrm{L}$. 0.292 g $\mathrm{C}_{2} \mathrm{H}_{4}$ per $\mathrm{L}$ and $0.195 \mathrm{~g} \mathrm{C}_{2} \mathrm{H}_{4}$ per $\mathrm{L}$ corresponding, respectively to $100 \%, 75 \%$ and $50 \%$ of the commercial dose. They were repeated with the addition of $2.86 \mathrm{~g}$ per $\mathrm{L}$ activated carbon (equal to a commercial dose of $20 \mathrm{~kg}$ activated carbon in $7,000 \mathrm{~L}$ of water per ha). Lastly, the Ethephon used was provided at $0.5 \mathrm{~kg}$ ethephon per ha dissolved in 2,000 $\mathrm{L}$ of water with $5 \%$ urea and brought at $\mathrm{pH} 3$.

The results concluded that the $\mathrm{C}_{2} \mathrm{H}_{4}$ and Zeothene dissolved in water were not seen to prove to be the best flowering agents. It was also seen that the optimal concentration of the $\mathrm{C}_{2} \mathrm{H}_{4}$ water treatment was suggested to lie at around $0.292 \mathrm{~g}$ per $\mathrm{L}$ or lower. It was also seen that activated carbon in low dosages did not bring about much change in inhomogeneity except in high concentrations of about 5\%. Additionally, it was found that the Ethephon posed the least homogeneity, possibly indicating retarded inflorescence development. Lastly, the application of these needs to be applied centrally to reach the plant apical meristem.

Aside from using zeothene and $\mathrm{C}_{2} \mathrm{H}_{4}$, another research study carried out by Valleser [129] used the flower induction treatment of Ethrel and Urea and was applied at approximately 11.5 MAP for the

e-ISSN: 2289-7771

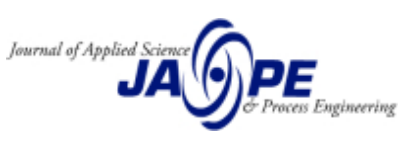


MD2 pineapples that they had grown. 155 days after the induction treatment, they also applied a fruit ripening solution of Ethrel and phosphoric acid. This ripening solution was put in place to help enhance the ripening of the pineapples. This inducing treatment was used for the experiment as it was believed to provide the best inducing yield. Furthermore, the study also attempted to determine the effect of different rates of Ethrel application on different ages of MD2 pineapple plants for flower induction. Valleser [129] also used a randomised block design and used MD2 pineapples 9, 10 and 11 MAP, and 0, 800,1,000 and 1,200 ppm of Ethrel as a subplot.

Based on these results, it was seen that all the plants were susceptible to ethrel, and an increase was seen after 18 days. According to Valleser [129], the plants are susceptible to chemical or environmental factors and hormones, specifically $\mathrm{C}_{2} \mathrm{H}_{4}$ as the main inducing factor. Ethrel or Ethephon which is $\mathrm{C}_{2} \mathrm{H}_{4}$ in liquid form, thereby triggers this increase as seen by the apical differentiation. These results also showed that plants above $3 \mathrm{MAP}$ were susceptible to $\mathrm{C}_{2} \mathrm{H}_{4}$ induction as they had reached maturity. Furthermore, plants that did not have any inducing factor showed low apical differentiation irrespective of age. It also suggested that plants of 9 MAP would have an optimum amount of 1,000 ppm Ethrel whereas that of 10 MAP would have suggested optimum rates of $800 \mathrm{ppm}$. It was concluded at the end that plants of 11 MAP showed the best response to the Ethrel at a rate of 1,200 ppm and induced the highest percentage of flowering.

Ethephon plays a factor in inducing the flowering in pineapples. However, this is not the only factor that needs to be considered as various external factors play a role in the flowering induction. According to Turnbull et al. [128], high temperatures may cause partial or total failure of the induction with ethephon. Therefore, it is very dependent on the ambient temperature and relative humidity. It is further seen that it is also relative to the $\mathrm{pH}$ of the inducer solution. Other factors include the concentration before absorption by the plant; the rain, which may cause the solution to be extracted from the leaf [130]; and high temperatures, which cause the product to undergo kinetic decomposition, thereby causing losses in $\mathrm{C}_{2} \mathrm{H}_{4}$ which may forcibly extract the solutions from the leaf. Lastly, solar radiation plays a factor, although the product is relatively stable in the presence of light [131]. Therefore, various variables play a role in the success of flowering with the use of ethephon. The factors that affect the efficiency of ethephon as a flowering agent include rain, temperature, and wind which affect the concentration of flora inducers, the absorption is affected by the Trichomes waxy layer circle stomata, and $\mathrm{pH}$, enzymes and temperature affect the decomposition of ethylene action for flowering [127].

Lastly, other research studies related to the flowering agent were carried out by Roy et al. [132] on the effect of alfa-naphthyl acetic acid and Ethrel on fruit growth and quality of Kew pineapple. After standard farming practices were carried out on the pineapple plant, $300 \mathrm{mg}$ per L naphthalene acetic acid (NAA) was applied between 30 to 90 days either once or twice after flower emergence, whereas Ethrel was also applied to the pineapples between 60 to 120 days of 0.25 or $0.5 \mathrm{~mL}$ per L. This research showed that treatments at 45 days and again at 60 days showed the highest yields of pineapple of 81 to 81.8 tonnes per ha. However, these treatments also decreased the soluble sugar content, TSS, and increased fruit acidity. Thereby, NAA is a commonly used flower inducer for pineapples due to the low cost and ability to induce pineapples similarly to other inducing agents.

\section{Similarities and differences in paddy, oil palm and pineapple management}

Although there are variations in the management of the three different crops, there are also some similarities. The use of fertilisers is almost essential for all crops as nutrient uptake is vital in helping the crops grow. The use of organic and inorganic fertilisers in paddy plantations showed a great increase in crop production with inorganic fertiliser being more harmful to the environment but providing better nutrient growth [94] [102]. This similarity is seen in pineapple management whereby the use of fertilisers with a higher $\mathrm{N}$ and $\mathrm{K}$ ratio increase the pineapple growth and yield while in the oil palm industry, good fertiliser practices enhance growth [120] [109]. Plant maturity and size of

e-ISSN: 2289-7771

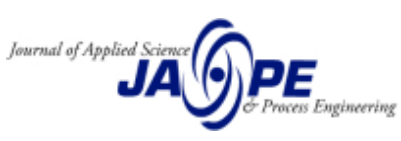


leaves play a big factor in the management of pineapples and paddy plantations. The plant size for paddy shows that the correct size results in higher yields whereas shorter or longer sizes in the paddy plant result in insufficient growth and rice lodging respectively [48]. In pineapple plantations, the plant size is used to determine maturity before the induction of the pineapples to result in a better yield of pineapples [129].

In oil palm management, the management of leaching and soil conditions plays an important role in helping the plants retain nutrients that are needed for their growth. Priority should be given to ensure the nutrients in the soils do not leach out to enable plants to constantly grow and produce FFB for numerous years. In pineapple plantation management, unlike that for paddy or oil palm, induction of pineapples is necessary, and the type of inducer used plays a role in the yield of pineapples [128]. Different inducing factors can be used based on the climatic conditions and ease of application with some applied numerous times to increase yields. The similarities and differences in these plantation managements vary due to the nature of the crops.

\section{Summary}

The rise in the number of human populations leads to a higher demand for crop products. To fulfil this high demand, the use of advanced technology such as fertilisers and induction agents plays a major role in increasing the overall crop yield. In addition, effective crop management strategies are required for the environment and to increase crop productivity.

\section{Recommendations}

A recommendation is made to conduct more agricultural-related research at the national level, especially local studies on the effect of fertiliser application in the plantations of paddy, oil palm, and pineapples, which are currently found lacking in the research studies. Agricultural studies that have been conducted by researchers are mostly conducted outside of Malaysia. There is a possibility that these findings may not apply to the country's agricultural industry due to variations in climate, local soil conditions, and agricultural practices. Additionally, doing local research in the agriculture field can promote a better economic implication to the country and the livelihood of the local farmers.

\section{Acknowledgements}

The authors would like to thank Curtin University Malaysia, Botanium Agro-Tech (M) Sdn. Bhd. and Koperasi Pembangunan Pertanian Bersatu Timur Bhd. for providing the financial support for this research project.

\section{References}

[1] Xu, Y., Ma, K., Zhao, Y., Wang, X., Zhou, K., Yu, G., Li, C., Li, P., Yang, Z., Xu, C., \& Xu, S. (2021, 2021/06/01/). Genomic selection: A breakthrough technology in rice breeding. The Crop Journal, 9(3), 669-677. https://doi.org/https://doi.org/10.1016/j.cj.2021.03.008

[2] Shahbandeh, M. (2020). World production volume of milled rice from 2008/2009 to 2019/2020. https://www.statista.com/statistics/271972/world-husked-rice-production-volume-since-2008/

[3] Dong, W., Zhang, X., Wang, H., Dai, X., Sun, X., Qiu, W., \& Yang, F. (2012). Effect of different fertilizer application on the soil fertility of paddy soils in red soil region of southern China. PloS one, 7(9).

[4] Malaysian Palm Oil Board. (2017). Malaysian Oil Palm Statistics 2016 (1511743X). http://palmshoppe.mpob.gov.my/mpob/index.php?route=product/product\&product $\mathrm{id}=117$

e-ISSN: 2289-7771

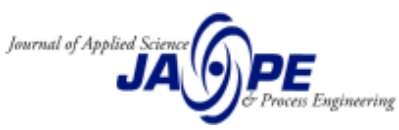


[5] Young, K. I., Buenemann, M., Vasilakis, N., Perera, D., \& Hanley, K. A. (2021, 2021/04/01). Shifts in mosquito diversity and abundance along a gradient from oil palm plantations to conterminous forests in Borneo ]. Ecosphere, 12(4), e03463. https://doi.org/10.1002/ecs2.3463

[6] Euler, M., Hoffmann, M. P., Fathoni, Z., \& Schwarze, S. (2016, 2016/07/01/). Exploring yield gaps in smallholder oil palm production systems in eastern Sumatra, Indonesia. Agricultural Systems, 146, 111119. https://doi.org/https://doi.org/10.1016/j.agsy.2016.04.007

[7] Malaysian Palm Oil Board. (2019). Oil Palm Planted Areas 2019. http://bepi.mpob.gov.my/index.php/en/area/area-2019/oil-palm-planted-area-as-at-dec-2019.html

[8] Malaysian Palm Oil Board. (2017). Review of The Malaysian Oil Palm Industry 2016. M. P. O. Board. http://palmshoppe.mpob.gov.my/mpob/index.php?route=product/product\&product id=118

[9] Abdullah, R. (2013). An analysis on trends of vegetable oil prices and some factors affecting. Oil Palm Indonesia Economic Journal, 13, 1-14.

[10] Dardak, R. A. (2019). Trends in Production, Trade, and Consumption of Tropical fruits in Malaysia. F. a. F. T. f. t. A. a. P. Region. https://ap.fftc.org.tw/article/1381

[11] Thalip, A. A., Tong, P.S., \& Ng, C. (2015). The MD2 "Super Sweet" Pineapple (Ananas comosus). Utar Agriculture Science Journal, 1, 15-17. ISSN 2289-957X (2015)

[12] Rehman, A., Chandio, A. A., Hussain, I., \& Jingdong, L. (2019). Fertilizer consumption, water availability and credit distribution: Major factors affecting agricultural productivity in Pakistan. Journal of the Saudi Society of Agricultural Sciences, 18(3), 269-274. https://doi.org/10.1016/j.jssas.2017.08.002

[13] Food and Agriculturure Organization of the United Nations. (2017). World Fertilizer Trends and Outlook to 2020. FAO. http://www.fao.org/publications/card/en/c/cfa19fbc-0008-466b-8cc6-0db6c6686f78/

[14] Trenkel, M. E. (2010). Slow-and controlled-release and stabilized fertilizers: an option for enhancing nutrient use efficiency in agriculture. IFA, International fertilizer industry association.

[15] Morgan, K. T., Cushman, K. E., \& Sato, S. (2009). Release mechanisms for slow-and controlled-release fertilizers and strategies for their use in vegetable production. HortTechnology, 19(1), 10-12. https://doi.org/10.21273/HORTSCI.19.1.10

[16] Simonne, E.H., \& Hutchinson, C.M. (2005). Controlled-release fertilizers for vegetable in the era of best management practices: Teaching new tricks to an old dog. HortTechnology, 15, 36-46. https://doi.org/10.21273/HORTTECH.15.1.0036

[17] Huang, J., He, F., Cui, K., Buresh, R. J., Xu, B., Gong, W., \& Peng, S. (2008). Determination of optimal nitrogen rate for rice varieties using a chlorophyll meter. Field Crops Research, 105(1-2), 70-80. https://doi.org/10.1016/j.fcr.2007.07.006

[18] Fageria, V. (2001). Nutrient interactions in crop plants. Journal of plant nutrition, 24(8), 1269-1290. https://doi.org/10.1081/PLN-100106981

[19] Fageria, N. K., Baligar, V. C., \& Jones, C. A. (2010). Growth and mineral nutrition of field crops. CRC Press.

[20] Rietra, R. P., Heinen, M., Dimkpa, C. O., \& Bindraban, P. S. (2017). Effects of nutrient antagonism and synergism on yield and fertilizer use efficiency. Communications in Soil Science and Plant Analysis, 48(16), 1895-1920. https://doi.org/10.1080/00103624.2017.1407429

[21] Lai, C. H., Settinayake, A. R. H., Yeo, W. S., Lau, S. W., \& Jong, T. K. (2019, 2019/09/25). Crop Nutrients Review and the Impact of Fertilizer on the Plantation in Malaysia: A Mini Review. Communications in Soil Science and Plant Analysis, 50(17), 2089-2105. https://doi.org/10.1080/00103624.2019.1654510

[22] Glick, B. R. (2012). Plant growth-promoting bacteria: mechanisms and applications. Scientifica, 2012. https://doi.org/10.6064/2012/963401

[23] Pittol, M., Scully, E., Miller, D., Durso, L., Mariana Fiuza, L., \& Valiati, V. H. (2018). Bacterial community of the rice floodwater using cultivation-independent approaches. International Journal of Microbiology, 2018. https://doi.org/10.1155/2018/6280484

e-ISSN: 2289-7771

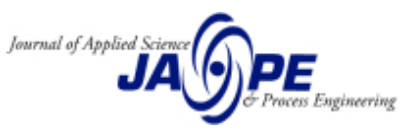


[24] Doni, F., Al-Shorgani, N. K. N., Abuelhassan, N. N., Isahak, A., Zain, C. R. C. M., \& Yusoff, W. M. W. (2013). Microbial involvement in growth of paddy. Current Research Journal of Biological Sciences, 5(6), 285-290. ISSN:2041-076X

[25] Chauhan, H., Bagyaraj, D., Selvakumar, G., \& Sundaram, S. (2015). Novel plant growth promoting rhizobacteria-Prospects and potential. Applied Soil Ecology, 95, 38-53. https://doi.org/10.1016/j.apsoil.2015.05.011

[26] Paungfoo-Lonhienne, C., Redding, M., Pratt, C., \& Wang, W. (2019). Plant growth promoting rhizobacteria increase the efficiency of fertilisers while reducing nitrogen loss. Journal of environmental management, 233, 337-341. https://doi.org/10.1016/j.jenvman.2018.12.052

[27] Mhatre, P. H., Karthik, C., Kadirvelu, K., Divya, K., Venkatasalam, E., Srinivasan, S., Ramkumar, G., Saranya, C., \& Shanmuganathan, R. (2019). Plant growth promoting rhizobacteria (PGPR): A potential alternative tool for nematodes bio-control. Biocatalysis and agricultural biotechnology, 17, 119-128. https://doi.org/10.1016/j.bcab.2018.11.009

[28] Khatoon, H., Solanki, P., Narayan, M., Tewari, L., \& Rai, J. (2017). Role of microbes in organic carbon decomposition and maintenance of soil ecosystem. International Journal of Chemical Studies, 5(6), 16481656. E-ISSN: 2321-4902

[29] Silhavy, T. J., Kahne, D., \& Walker, S. (2010). The bacterial cell envelope. Cold Spring Harbor perspectives in biology, 2(5), a000414. doi:10.1101/cshperspect.a000414

[30] Cornelis, P. (2010). Iron uptake and metabolism in pseudomonads. Applied microbiology and biotechnology, 86(6), 1637-1645. https://doi.org/10.1007/s00253-010-2550-2

[31] Mohammadinejhad-Babandeh, S., Doroodian, H., \& Besharati, H. (2012). Effect of bio-bacterial (Azetobacter, Azorhizobioum, Azospirilium) on yield and yield components of rice in Bandar-Anzali, north of Iran. Research Journal of Biological Sciences, 7(6), 244-249. ISSN :1815-8846

[32] Tian, B., Yang, J., Lian, L., Wang, C., \& Zhang, K. (2007). Role of neutral protease from Brevibacillus laterosporus in pathogenesis of nematode. Appl Microbiol Biotechnol, 74, 372-380.

[33] Zaidi, A., Khan, M., Ahemad, M., \& Oves, M. (2009). Plant growth promotion by phosphate solubilizing bacteria. Acta microbiologica et immunologica Hungarica, 56(3), 263-284. https://doi.org/10.1556/amicr.56.2009.3.6

[34] Siddiqui, I. A., Haas, D., \& Heeb, S. (2005). Extracellular protease of Pseudomonas fluorescens CHA0, a biocontrol factor with activity against the root-knot nematode Meloidogyne incognita. Appl. Environ. Microbiol., 71(9), 5646-5649. https://doi.org/10.1128/AEM.71.9.5646-5649.2005 •

[35] Mishra, D., \& Sinha, A. (2000). Plant growth-promoting activity of some fungal and bacterial agents on rice seed germination and seedling growth. Tropical agriculture, 77(3), 188-191. ISSN: 0041-3216

[36] Banaay, C., Cuevas, V., \& Cruz, C. V. (2012). Trichoderma ghanense promotes plant growth and controls disease caused by Pythium arrhenomanes in seedlings of aerobic rice variety apo. The Philippine Agricultural Scientist, 95(2). ISSN 0031-7454

[37] Amprayn, K.-o., Rose, M. T., Kecskés, M., Pereg, L., Nguyen, H. T., \& Kennedy, I. R. (2012). Plant growth promoting characteristics of soil yeast (Candida tropicalis HY) and its effectiveness for promoting rice growth. Applied Soil Ecology, 61, 295-299. https://doi.org/10.1016/j.apsoil.2011.11.009

[38] Sohrabi, M., Rafii, M., Hanafi, M., Siti Nor Akmar, A., \& Latif, M. (2012). Genetic diversity of upland rice germplasm in Malaysia based on quantitative traits. The Scientific World Journal, 2012. https://doi.org/10.1100/2012/416291

[39] Nazuri, N. S., \& Man, N. (2016). Acceptance and practices on new paddy seed variety among farmers in MADA granary area. Academic Journal of Interdisciplinary Studies, 5(2), 105-105. DOI: 10.5901/ajis.2016.v5n2p105

[40] Miah, G., Rafii, M. Y., Ismail, M. R., Puteh, A. B., Rahim, H. A., Islam, K., \& Latif, M. A. (2013). A review of microsatellite markers and their applications in rice breeding programs to improve blast disease resistance. International journal of molecular sciences, 14(11), 22499-22528. https://doi.org/10.3390/ijms141122499 
[41] Suswanto, T., Shamshuddin, J., Syed Omar, S., Mat, P., \& Teh, C. (2007). Effects of lime and fertiliser application in combination with water management on rice (Oryza sativa) cultivated on an acid sulfate soil. Malaysian Journal of Soil Science, 11, 1-16. ISSN: 1394-7990

[42] Tzyy Jiann Chong, E., Poh Wah Goh, L., Jun Wong, J., Aziz, Z. A., Latip, M. A., \& Lee, P.-C. (2018). Genetic Diversity and Relationship of Sabah Traditional Rice Varieties as Revealed by RAPD Markers. Pertanika Journal of Topical Agricultural Science, 41(1). ISSN: 1511-3701

[43] Wang, Z. Y., Zheng, F. Q., Shen, G. Z., Gao, J. P., Snustad, D. P., Li, M. G., Zhang, J. L., \& Hong, M. M. (1995). The amylose content in rice endosperm is related to the post-transcriptional regulation of the waxy gene. The Plant Journal, 7(4), 613-622. https://doi.org/10.1046/j.1365-313X.1995.7040613.x

[44] Chen, E., Huang, X., \& Han, B. (2016). How can rice genetics benefit from rice-domestication study. National Science Review, 3(3), 278-280.

[45] Confalonieri, R., Bregaglio, S., Rosenmund, A. S., Acutis, M., \& Savin, I. (2011). A model for simulating the height of rice plants. European journal of agronomy, 34(1), 20-25. https://doi.org/10.1016/j.eja.2010.09.003

[46] Sritarapipat, T., Rakwatin, P., \& Kasetkasem, T. (2014). Automatic rice crop height measurement using a field server and digital image processing. Sensors, 14(1), 900-926. https://doi.org/10.3390/s140100900

[47] Majda, M., \& Robert, S. (2018). The role of auxin in cell wall expansion. International journal of molecular sciences, 19(4), 951. https://doi.org/10.3390/ijms19040951

[48] Zhang, Y., Yu, C., Lin, J., Liu, J., Liu, B., Wang, J., Huang, A., Li, H., \& Zhao, T. (2017). OsMPH1 regulates plant height and improves grain yield in rice. PloS one, 12(7). https://doi.org/10.1371/journal.pone.0180825

[49] Ambhore, J. (2015). Aeromycological studies over maize and paddy crops. Lulu. com.

[50] Zhang, B., Ye, W., Ren, D., Tian, P., Peng, Y., Gao, Y., Ruan, B., Wang, L., Zhang, G., \& Guo, L. (2015). Genetic analysis of flag leaf size and candidate genes determination of a major QTL for flag leaf width in rice. Rice, 8(1), 2. https://doi.org/10.1186/s12284-014-0039-9

[51] Flügge, U.-I., Westhoff, P., \& Leister, D. (2016). Recent advances in understanding photosynthesis. F1000Research, 5.

[52] Wang, P., Zhou, G., Yu, H., \& Yu, S. (2011). Fine mapping a major QTL for flag leaf size and yield-related traits in rice. Theoretical and applied genetics, 123(8), 1319-1330. DOI 10.1007/s00122-011-1669-6

[53] Yang, Y., Zhang, M., Xu, Q., Feng, Y., Yuan, X., Yu, H., Wang, Y., \& Wei, X. (2018). Exploration of genetic selection in rice leaf length and width. Botany, 96(4), 249-256. https://doi.org/10.1139/cjb-2017$\underline{0161}$

[54] Wu, J., Qi, Y., Hu, G., Li, J., Li, Z., \& Zhang, H. (2017). Genetic architecture of flag leaf length and width in rice (Oryza sativa L.) revealed by association mapping. Genes \& Genomics, 39(3), 341-352. DOI 10.1007/s13258-016-0501-8

[55] Yang, C., Yang, L., Yang, Y., \& Ouyang, Z. (2004). Rice root growth and nutrient uptake as influenced by organic manure in continuously and alternately flooded paddy soils. Agricultural Water Management, 70(1), 67-81. https://doi.org/10.1016/j.agwat.2004.05.003

[56] Qu, Y., Mu, P., Zhang, H., Chen, C. Y., Gao, Y., Tian, Y., Wen, F., \& Li, Z. (2008). Mapping QTLs of root morphological traits at different growth stages in rice. Genetica, 133(2), 187-200. DOI 10.1007/s10709$\underline{007-9199-5}$

[57] Zhao, Y., Jiang, C.-h., Rehman, R. M. A., Zhang, H.-1., Li, J., \& Li, Z.-c. (2019). Genetic analysis of roots and shoots in rice seedling by association mapping. Genes \& genomics, 41(1), 95-105. https://doi.org/10.1007/s13258-018-0741-x

[58] Chen, S., Wang, D., Xu, C., Ji, C., Zhang, X., Zhao, X., Zhang, X., \& Chauhan, B. S. (2014). Responses of super rice (Oryza sativa L.) to different planting methods for grain yield and nitrogen-use efficiency in the single cropping season. PloS one, 9(8). https://doi.org/10.1371/journal.pone.0104950

e-ISSN: 2289-7771

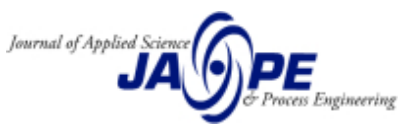


[59] Ehsanullah, I. I., Ahmad, A., \& Randhawa, S. A. (2000). Effect of direct seeding and transplanting methods on the yield and quality of fine rice Basmati-370. Indian Journal of Agroomy, 38, 547-550. 1560$\underline{8530 / 2000 / 02-3-251-252}$

[60] Birhane, A. (2013). Effect of planting methods on yield and yield components of Rice (Oryza sativa L.) varieties in Tahtay Koraro Wereda, Northern Ethiopia. International Journal of Technology Enhancements and Emerging Engineering Research, 1(5), 1-5. ISSN 2347-4289

[61] Ali, A., Erenstein, O., \& Rahut, D. B. (2014). Impact of direct rice-sowing technology on rice producers' earnings: Empirical evidence from Pakistan. Development Studies Research. An Open Access Journal, 1(1), 244-254. https://doi.org/10.1080/21665095.2014.943777

[62] Marasini, S., Joshi, T., \& Amgain, L. (2016). Direct seeded rice cultivation method: a new technology for climate change and food security. Journal of Agriculture and Environment, 17, 30-38. https://doi.org/10.3126/aej.v17i0.19857

[63] Naresh, R., Misra, A., \& Singh, S. (2013). Assessment of direct seeded and transplanting methods of rice cultivars in the western part of Uttar Pradesh. International Journal, 1(1). ISSN: 2310-6913

[64] Awan, T., Ahmad, M., Ashraf, M., \& Ali, I. (2011). Effect of different transplanting methods on paddy yield and its components at farmer's field in rice zone of Punjab. The Journal of Animal and Plant Sciences, 21(3), 498-502. ISSN: 1018-7081

[65] Peng, S., Tang, Q., \& Zou, Y. (2009). Current status and challenges of rice production in China. Plant Production Science, 12(1), 3-8. https://doi.org/10.1626/pps.12.3

[66] Jing, F., \& Yang, J.-c. (2012). Research advances in high-yielding cultivation and physiology of super rice. Rice Science, 19(3), 177-184. https://doi.org/10.1016/S1672-6308(12)60038-9

[67] Wang, D., Huang, J., Nie, L., Wang, F., Ling, X., Cui, K., Li, Y., \& Peng, S. (2017). Integrated crop management practices for maximizing grain yield of double-season rice crop. Scientific reports, 7, 38982. https://doi.org/10.1038/srep38982

[68] Wu, W., Nie, L., Liao, Y., Shah, F., Cui, K., Wang, Q., Lian, Y., \& Huang, J. (2013). Toward yield improvement of early-season rice: Other options under double rice-cropping system in central China. European journal of agronomy, 45, 75-86. https://doi.org/10.1016/j.eja.2012.10.009

[69] Ray, D. K., \& Foley, J. A. (2013). Increasing global crop harvest frequency: recent trends and future directions. Environmental Research Letters, 8(4), 044041. https://doi.org/10.1088/1748-9326/8/4/044041

[70] Wu, X. H., Wang, W., Yin, C. M., Hou, H. J., Xie, K. J., \& Xie, X. L. (2017). Water consumption, grain yield, and water productivity in response to field water management in double rice systems in China. PloS one, 12(12). https://doi.org/10.1371/journal.pone.0189280

[71] Bouman, B. (2009). How much water does rice use. Management, 69, 115-133.

[72] Tuong, T. P., BAM, B., \& Mortimer, M. (2005). More Rice, Less Water-Integrated Approaches for Increasing Water Productivity in Irrigated Rice-Based Systems in Asia-.Plant Production Science, 8(3), 231-241. https://doi.org/10.1626/pps.8.231

[73] Tuong, T., \& Bouman, B. (2003). Rice production in water-scarce environments. Water productivity in agriculture: Limits and opportunities for improvement, 1, 13-42. DOI : 10.1079/9780851996691.0053

[74] Chen, J. H. (2006). The combined use of chemical and organic fertilizers and/or biofertilizer for crop growth and soil fertility. In International workshop on sustained management of the soil-rhizosphere system for efficient crop production and fertilizer use, 16(20), 1-11. DOI: $10.30058 /$ SE.200706.0001

[75] Shah, F., \& Wu, W. (2019). Soil and crop management strategies to ensure higher crop productivity within sustainable environments. Sustainability, 11(5), 1485. https://doi.org/10.3390/su11051485

[76] Boulter, J. I., Trevors, J. T., \& Boland, G. J. (2002). Microbial studies of compost: bacterial identification, and their potential for turfgrass pathogen suppression. World Journal of Microbiology and Biotechnology, 18(7), 661-671. https://doi.org/10.1023/A:1016827929432

[77] McCauley, A., Jones, C., \& Jacobsen, J. (2009). Soil pH and organic matter. Nutrient management module, $8(2), 1-12$.

e-ISSN: 2289-7771

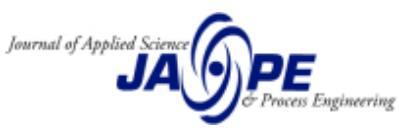


[78] Ilagan, L. A., Tablizo, R. P., Barba Jr, R. B., \& Marquez, N. (2014). Soil fertility evaluation for rice production in Catanduanes Province, Philippines. International Journal of Scientific and Technology Research, 3(12), 81-87. ISSN 2277-8616

[79] Othman, Z., Othman, S. N., \& Ab Hamid, K. (2013). Pengurusan Pertanian Lestari di Luar Bandar: Kes Projek Agropolitan di Kawasan Terbiar. Prosiding PERKEM VIII, JILID, 2, 790-795. ISSN: 2231-962X

[80] Nixon, S. W. (1995). Coastal marine eutrophication: a definition, social causes, and future concerns. Ophelia, 41(1), 199-219. https://doi.org/10.1080/00785236.1995.10422044

[81] Mohamed, Z., Terano, R., Shamsudin, M. N., \& Abd Latif, I. (2016). Paddy farmers' sustainability practices in granary areas in Malaysia. Resources, 5(2), 17. https://doi.org/10.3390/resources5020017

[82] Adhya, T. K., Lal, B., Mohapatra, B., Paul, D., \& Das, S. (2018). Advances in soil microbiology: recent trends and future prospects. Springer. https:/doi.org/10.1007/978-981-10-6178-3

[83] Murdoch, W. W., \& Briggs, C. J. (1996). Theory for biological control: recent developments. Ecology, 77(7), 2001-2013. https://doi.org/10.2307/2265696

[84] Dou, F., Soriano, J., Tabien, R. E., \& Chen, K. (2016). Soil texture and cultivar effects on rice (Oryza sativa, L.) grain yield, yield components and water productivity in three water regimes. PloS one, 11(3). https://doi.org/10.1371/journal.pone.0150549.s001

[85] Six, J., Paustian, K., Elliott, E. T., \& Combrink, C. (2000). Soil structure and organic matter I. Distribution of aggregate-size classes and aggregate-associated carbon. Soil Science Society of America Journal, 64(2), 681-689. https://doi.org/10.2136/sssaj2000.642681x

[86] Smith, S., \& De Smet, I. (2012). Root system architecture: insights from Arabidopsis and cereal crops. In: The Royal Society. https://doi.org/10.1098/rstb.2011.0234

[87] McMichael, B., \& Quisenberry, J. (1993). The impact of the soil environment on the growth of root systems. Environmental and Experimental Botany, 33(1), 53-61. https://doi.org/10.1016/0098$\underline{8472(93) 90055-\mathrm{K}}$

[88] Wang, Y., Thorup-Kristensen, K., Jensen, L. S., \& Magid, J. (2016). Vigorous root growth is a better indicator of early nutrient uptake than root hair traits in spring wheat grown under low fertility. Frontiers in plant science, 7, 865. http://dx.doi.org/10.3389/fpls.2016.00865

[89] Alam, M., Siwar, C., Talib, B., \& Toriman, M. (2014). Impacts of climatic changes on paddy production in Malaysia: Micro study on IADA at North West Selangor. Alam, MM, Siwar, C., Talib, B., and Mohd Ekhwan, 251-258. https://ssrn.com/abstract=2942638

[90] Hamidi, Z. S., Shariff, N., \& Monstein, C. (2014). Understanding climate changes in Malaysia through space weather study. International Letters of Natural Sciences, 8(1). ISSN :2300-9675

[91] Jamaludin, N., Mohammed, N. I., Khamidi, M. F., \& Wahab, S. N. A. (2015). Thermal comfort of residential building in Malaysia at different micro-climates. Procedia-Social and Behavioral Sciences, 170, 613-623. https://doi.org/10.1016/j.sbspro.2015.01.063

[92] Yan, C., Ding, Y., Wang, Q., Liu, Z., Li, G., Muhammad, I., \& Wang, S. (2010). The impact of relative humidity, genotypes and fertilizer application rates on panicle, leaf temperature, fertility and seed setting of rice. The Journal of Agricultural Science, 148(3), 329-339. https://doi.org/10.1017/S0021859610000018

[93] Ko, J., Kim, H.-Y., Jeong, S., An, J.-B., Choi, G., Kang, S., \& Tenhunen, J. (2014). Potential impacts on climate change on paddy rice yield in mountainous highland terrains. Journal of Crop Science and Biotechnology, 17(3), 117-126. DOI No. 10.1007/s12892-013-0110-x

[94] Wang, W., Xie, X., Chen, A., Yin, C., \& Chen, W. (2013). Effects of long-term fertilization on soil carbon, nitrogen, phosphorus and rice yield. Journal of plant nutrition, 36(4), 551-561. https://doi.org/10.1080/01904167.2012.748795

[95] Masni, Z., \& Wasli, M. (2019). Yield Performance and Nutrient Uptake of Red Rice Variety (MRM 16) at Different NPK Fertilizer Rates. International Journal of Agronomy, 2019. https://doi.org/10.1155/2019/5134358

[96] Han, S. H., An, J. Y., Hwang, J., Kim, S. B., \& Park, B. B. (2016). The effects of organic manure and chemical fertilizer on the growth and nutrient concentrations of yellow poplar (Liriodendron tulipifera Lin.)

e-ISSN: 2289-7771

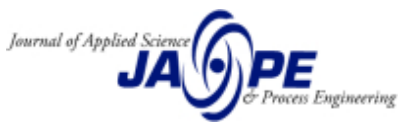


in a nursery system. Forest science and Technology, 12(3), 137-143. https://doi.org/10.1080/21580103.2015.1135827

[97] Allen, P., \& Kovach, M. (2000). The capitalist composition of organic: The potential of markets in fulfilling the promise of organic agriculture. Agriculture and human values, 17(3), 221-232. https://doi.org/10.1023/A:1007640506965

[98] Lin, W., Lin, M., Zhou, H., Wu, H., Li, Z., \& Lin, W. (2019). The effects of chemical and organic fertilizer usage on rhizosphere soil in tea orchards. PloS one, 14(5). https://doi.org/10.1371/journal.pone.0217018

[99] Li, Y. C., Li, Z. W., Lin, W. W., Jiang, Y. H., Weng, B. Q., \& Lin, W. X. (2018). Effects of biochar and sheep manure on rhizospheric soil microbial community in continuous ratooning tea orchards. Ying yong sheng tai xue bao= The journal of applied ecology, 29(4), 1273-1282. https://doi.org/10.13287/j.10019332.201804.036

[100]Masarirambi, M., Hlawe, M. M., Oseni, O. T., \& Sibiya, T. (2010). Effects of organic fertilizers on growth, yield, quality and sensory evaluation of red lettuce (Lactuca sativa L.)'Veneza Roxa'. Agriculture and Biology Journal of North America, 1(6), 1319-1324. DOI : 10.5251/abjna.2010.1.6.1319.1324

[101]Sharma, A., \& Chetani, R. (2017). A review on the effect of organic and chemical fertilizers on plants. International Journal for Research in Applied Science \& Engineering Technology (IJRASET), 5(2), 677680. ISSN: 2321-9653

[102]Ojeniyi, S. (2002). Soil management, national resources and environment. Nigeria Journal of Soil Science, 16, 131-135.

[103]Mofunanya, A., Ebigwai, J., Bello, O., \& Egbe, A. (2015). Comparative study of the effects of organic and inorganic fertilizer on nutritional composition of Amaranthus spinosus L. Asian Journal of Plant Sciences, 14(1), 34-39. DOI : 10.3923/ajps.2015.34.39

[104]Gupta, V., Lawrence, J., \& Germida, J. (1988). Impact of elemental sulfur fertilization on agricultural soils. I. Effects on microbial biomass and enzyme activities. Canadian Journal of Soil Science, 68(3), 463-473. https://doi.org/10.4141/cjss88-045

[105]Shahbandeh, M. (2019). Production volume of palm oil worldwide from 2012/13 to 2019/20. Statisca.com. https://www.statista.com/statistics/613471/palm-oil-production-volume-worldwide/

[106]Carlson, K. M., Heilmayr, R., Gibbs, H. K., Noojipady, P., Burns, D. N., Morton, D. C., Walker, N. F., Paoli, G. D., \& Kremen, C. (2018). Effect of oil palm sustainability certification on deforestation and fire in Indonesia. Proceedings of the National Academy of Sciences, 115(1), 121-126. https://doi.org/10.1073/pnas.1704728114

[107]CEIC. (2019). Malaysia: Crude Palm Oil Production. Retrieved September 21 from https://www.ceicdata.com/en/blog/malaysia-crude-palm-oil-production

[108]Goh, K., Teo, C., Chew, P., \& Chiu, S. (1999). Fertiliser management in oil palm-agronomic principles and field practices. Fertilizer Management for Oil Palm Plantations, Sandakan, Malaysia, 20, 21.

[109]Pretty, K., \& Sanders, J. (1984). Maximizing the yield of perennial crops through integrated management.

[110]Maene, L., Thong, K., Ong, T., \& Mokhtaruddin, A. (1979). Surface wash under mature oil palm. Malaysian Society of Soil Science.

[111]Rashmi, I., Shirale, A., Kartikha, K., Shinogi, K., Meena, B., \& Kala, S. (2017). Leaching of Plant Nutrients from Agricultural Lands. In Essential Plant Nutrients (pp. 465-489). Springer. https://doi.org/10.1007/978-3-319-58841-4_19

[112]Luo, J., De Klein, C., Ledgard, S., \& Saggar, S. (2010). Management options to reduce nitrous oxide emissions from intensively grazed pastures: a review. Agriculture, ecosystems \& environment, 136(3-4), 282-291. https://doi.org/10.1016/j.agee.2009.12.003

[113]Howarth, R. W., Sharpley, A., \& Walker, D. (2002). Sources of nutrient pollution to coastal waters in the United States: Implications for achieving coastal water quality goals. Estuaries, 25(4), 656-676. https://doi.org/10.1007/BF02804898

e-ISSN: 2289-7771

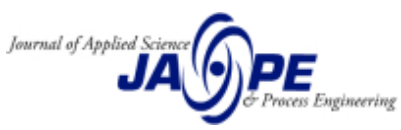


[114]Žemlička, L., Fodran, P., Kolek, E., \& Prónayová, N. (2013). Analysis of natural aroma and flavor of MD2 pineapple variety (Ananas comosus [L.] Merr.). Acta Chimica Slovaca, 6(1), 123-128. DOI: 10.2478/acs$\underline{2013-0019}$

[115]Sanewski, G. M., Bartholomew, D. P., \& Paull, R. E. (2018). The pineapple: botany, production and uses. CABI. http://dx.doi.org/10.1079/9781786393302.0000

[116]Workman, D. (2017). Bananas Exports by Country. Disponible en línea: Disponible en línea: http://www. worldstopexports. com/bananas-exports-country/. Fecha de consulta, 24.

[117]Compilation, T. N. (2016). Pineapple - Common Varieties. International Tropical Fruits Network. Retrieved 18/02/2021 from https://www.itfnet.org/v1/2016/05/pineapple-common-varieties/

[118]Sideris, C., \& Young, H. (1945). Effects of potassium on chlorophyll, acidity, ascorbic acid, and carbohydrates of Ananas comosus (L.) Merr. Plant physiology, 20(4), 649. doi: 10.1104/pp.20.4.649

[119]Mohamed, M., Padmanabhan, E., Mei, B., \& Siong, W. (2002). The peat soils of Sarawak. STRAPEAT Status Report. Universiti Malaysia Sarawak, Malaysia.

[120]Spironello, A., Quaggio, J. A., Teixeira, L. A. J., Furlani, P. R., \& Sigrist, J. M. M. (2004). Pineapple yield and fruit quality effected by NPK fertilization in a tropical soil. Revista brasileira de fruticultura, 26(1), 155-159. https://doi.org/10.1590/S0100-29452004000100041

[121]Omotoso, S., \& Akinrinde, E. (2013). Effect of nitrogen fertilizer on some growth, yield and fruit quality parameters in pineapple (Ananas comosus L. Merr.) plant at Ado-Ekiti Southwestern, Nigeria. Int. Res. J. Agric. Sci. Soil Sci, 3(1), 11-16. ISSN: 2251-0044

[122]Valleser, V. C. (2019). Phosphorus Nutrition Provoked Improvement on the Growth and Yield of'MD2'Pineapple. Pertanika Journal of Tropical Agricultural Science, 42(2). ISSN: 1511-3701

[123]Ball, J. (2007). Back to Basics: The Roles of N, P, K and Their Sourced. Ag News and.

[124]Teixeira, L. A. J., Quaggio, J. A., Cantarella, H., \& Mellis, E. V. (2011). Potassium fertilization for pineapple: effects on soil chemical properties and plant nutrition. Revista brasileira de fruticultura, 33(2), 627-636. https://doi.org/10.1590/S0100-29452011000200036

[125]Kleinhenz, V. (1998). Sulfur and chloride in the soil-plant system. Central Queensland Univ.

[126]Marschner, H. (2011). Marschner's mineral nutrition of higher plants. Academic press. ISBN: 978-0-12$\underline{384905-2}$

[127]Cunha, G. A. P. d. (2005). Applied aspects of pineapple flowering. Bragantia, 64(4), 499-516. https://doi.org/10.1590/S0006-87052005000400001

[128]Turnbull, C., Sinclair, E., Anderson, K., Nissen, R., Shorter, A., \& Lanham, T. (1999). Routes of ethephon uptake in pineapple (Ananas comosus) and reasons for failure of flower induction. Journal of plant growth regulation, 18(4), 145-152. https://doi.org/10.1007/PL00007062

[129]Valleser, V. C. (2018, 2018). Plant Age and Rate of Flower Inducer Affects Flower Initiation of 'MD2' Pineapple (Ananas comosus L.). International Journal of Research \& Review, 5(4). E-ISSN: 2349-9788

[130]Py, C., Lacoeuilhe, J. J., \& Teisson, C. (1987). The pineapple. Cultivation and uses. G.-P. Maisonneuve et Larose. ISBN : 2-7068-0844-6. ISBN 2-7068-0948-5

[131]Biddle, E., Kerfoot, D. G., Kho, Y. H., \& Russell, K. E. (1976). Kinetic studies of the thermal decomposition of 2-chloroethylphosphonic acid in aqueous solution. Plant physiology, 58(5), 700-702. https://doi.org/10.1104/pp.58.5.700

[132]Roy, A., Sen, S., \& Bose, T. (1980). Effect of alfa-naphthylacetic acid and Ethrel on fruit growth and quality of Kew pineapple. Bangladesh Horticulture, 8(2), 13-20. ISSN:0379-4288

e-ISSN: 2289-7771

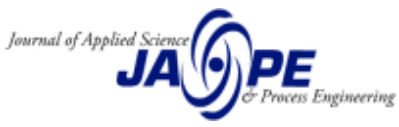

